\title{
Assessment of the Impacts of Climate Change on European Ozone Levels
}

\author{
K. V. Varotsos • C. Giannakopoulos $・$ M. Tombrou
}

Received: 6 December 2012 / Accepted: 9 May 2013 /Published online: 25 May 2013

(C) Springer Science+Business Media Dordrecht 2013

\begin{abstract}
The objective of this study is to investigate the potential impact of future climate change on ozone air quality in Europe. To provide a full assessment, simulations with the global chemical transport model GEOSCHEM driven by the NASA Goddard Institute for Space Studies general circulation model (NASA/GISS GCM) are conducted. To isolate the effects from changes in climate and anthropogenic emissions four types of simulations are performed: (1) present-day climate and emissions (2) future climate following the IPCC Special Report on Emission Scenarios (SRES) A1B scenario and present-day anthropogenic emissions of ozone precursors (3) present-day climate and future emissions and (4) future climate and future emissions. Results indicate that climate change impact on its own leads to an increase of less than $3 \mathrm{ppb}$ in western and central Europe whereas decreases are evident for the rest of the areas with the highest (about $2.5 \mathrm{ppb}$ ) in southeastern Europe (Italy, Greece). Increases are attributed to the increases of isoprene biogenic emissions due to increasing temperatures whereas decreases are associated with the increase of water vapor over sea which tends to decrease the lifetime of ozone as well as the increased wind speeds in the 2050
\end{abstract}

\footnotetext{
K. V. Varotsos $\cdot$ M. Tombrou

Division of Environmental Physics and Meteorology, National and Kapodistrian University of Athens,

Athens, Greece

C. Giannakopoulos $(\bowtie)$

Institute for Environmental Research and Sustainable

Development, National Observatory of Athens,

Athens, Greece

e-mail: cgiannak@meteo.noa.gr
}

climate. When future emissions are implemented in the future climate simulations, the greatest increases are seen in the southwest and southeast Mediterranean (about $16 \mathrm{ppb}$ ) due to the increased isoprene biogenic emissions under higher levels of $\mathrm{NO}_{x}$ in the model. Decreases up to $2 \mathrm{ppb}$ of ozone are shown for France, Switzerland, Northern Italy and northern Europe.

Keywords Climate change $\cdot$ Ozone $\cdot$ Europe $\cdot$ Future emissions

\section{Introduction}

Climate change impact on ozone air-quality is an area of research that has evolved over the last decade based on the assumption that air quality is strongly dependent on weather systems and is therefore sensitive to climate change. Changes in climate affect air quality through alteration in air pollution meteorology (Rind et al. 2001; Mickley et al. 2004; Leung and Gustafson 2005; Wu et al. 2008) affecting ventilation rates, precipitation scavenging, dry deposition, chemical production and loss rates, natural emissions and background concentrations. Moreover, high concentrations of ozone affect human health (Bell et al. 2007; Selin et al. 2009) and therefore considerable responsibility is placed on scientists to accurately predict ozone pollution levels so that the adverse health effects of air pollution can be minimized.

A number of studies have recently been published focusing over areas with increased anthropogenic activities using global and/or regional climate-chemical 
3D modeling systems (Jacob and Winner 2009 and references therein; Katragkou et al. 2011 and references therein). Regarding Europe, a wide range of results exists in literature regarding the regional patterns of future ozone, associated with the modeling systems used, the time slices investigated as well as the quality of climatic data that drove the simulations (Langner et al. 2005; Forkel and Knoche 2006, 2007; Meleux et al. 2007; Giorgi and Meleux 2007; Hedegaard et al. 2008; Andersson and Engardt 2010; Katragkou et al. 2011; Langner et al. 2012). The majority of the aforementioned studies were conducted in an off-line mode using either constant initial and boundary conditions with no seasonal variation (Katragkou et al. 2011) or prescribed monthly climatologies from global (Meleux et al. 2007) or hemispheric chemical transport models (Langner et al. 2012). Regarding their results, ozone behavior under climate change has been found to be affected by changes in temperature, solar radiation, biogenic emissions, cloudiness and precipitation, snow cover, dry deposition as well as changes in circulation patterns (Katragkou et al. 2011 and references therein). In particular, ozone summer increases in Southern, Central and North West Europe were attributed to a combination of increases in temperature, biogenic emissions solar radiation and dry deposition as well as to decreases in cloudiness and precipitation which reduces the wet deposition of ozone. On the contrary, decreases in the ozone concentrations mostly found in the northern European regions were attributed to decreased snow cover which enhances ozone dry deposition, decreased solar radiation as well as increases in cloudiness and precipitation. All the above studies examined changes in ozone induced solely by changes in climate, which effectively means that present and future simulations were conducted using present-day emissions.

The objective of this study is to investigate the impact of future climate change on ozone airquality in Europe using the Goddard Institute for Space Studies (GISS)/GEOS-CHEM global climatechemistry model. In order to provide a full assessment of the future ozone concentration, apart from examining the climate change impact on its own, simulations with future anthropogenic emissions estimates derived from A1B (Nakicenovic and Swart 2000) scenario are also conducted. By including simulations with future anthropogenic emissions estimates we extend the analysis of the changes of future ozone concentrations. Before presenting the results of the impacts of climate change on ozone an evaluation of the GISS/GEOS-CHEM modeling system is also presented.

\section{Simulations, Data Sources and Methods}

\subsection{The GISS/GEOS-CHEM Global Modeling System}

The GEOS-CHEM is a 3-D chemical transport model developed by the Atmospheric Chemistry Modeling Group of Harvard University (http:// acmg.seas.harvard.edu/) which has been used for various studies in the troposphere including Europe (Duncan and Bey 2004; Auvray and Bey 2005; Guerova and Jones 2007; Protonotariou et al. 2010). The GEOS-Chem (version 8-03-01) includes a fully coupled treatment of tropospheric ozone- $\mathrm{NO}_{x}-\mathrm{VOC}$ chemistry and aerosols. In this study, GEOS-CHEM is coupled in an off-line mode to the NASA/GISS III general circulation model (GCM) (Rind et al. 2001) and used to investigate ozone air quality in Europe under present and future climate. In the current study, the GEOS-CHEM simulations are driven by 6 -h meteorological data averages such as wind, convective mass flux, temperature, humidity, cloud optical depths, and cloud fraction, 3-h average data of mixing depth and surface variables such as precipitation, wind, temperature, albedo and solar radiation (Wu et al. 2007, 2008). The horizontal resolution is $4^{\circ} \times 5^{\circ}$ with 23 vertical levels extending up to $0.02 \mathrm{hPa}$. Although global models are useful tools to predict long term climate and air quality trends, their coarse resolution is a limiting factor in resolving phenomena relevant to air quality at small scales such as meteorology features at areas with complex terrain (Jacob and Winner 2009).

For the purposes of this study four scenario simulations are performed: (a) present-day climate and presentday emissions (hereafter SCEN_1), (b) future climate following the IPCC Special Report on Emission Scenarios (SRES) A1B scenario (Nakicenovic and Swart 2000) and present-day anthropogenic emissions of ozone precursors (hereafter SCEN_2), (c) presentday climate and future emissions (hereafter SCEN_3) and (d) future climate and emissions (hereafter SCEN_4). The base year anthropogenic emissions inventory is 2000 while for the future anthropogenic 
emissions growth factors based on the A1B scenario are applied on the present-day emissions as similar to Wu et al. (2008). In particular, the growth factors are applied on different categories of the present-day anthropogenic emissions such as fossil fuel, biomass fuel and biomass burning and for different countries to provide estimates for the 2050 future anthropogenic emissions based on the results of the IMAGE (Integrated Model to Assess the Greenhouse Effect) socioeconomic model (Streets et al. 2004; Wu et al. 2008). Similar to Wu et al. (2008) biomass burning is the sum of forest fires, grassland fires, and infield crop burning.

The model's inventory also includes natural emissions of ozone precursors such as non-methane volatile organic compounds (NMVOCs) from vegetation and $\mathrm{NO}_{x}$ from soil and lightning which are calculated within the model and are allowed to vary with the meteorological variables. NMVOCs vary only with temperature and solar radiation. In Table 1, the European and the global emissions of anthropogenic and natural emissions of ozone precursors used in the current study are listed for both the present and the
2050 s climate. An analytical description of the model is provided by $\mathrm{Wu}$ et al. (2008).

The simulations performed here cover two 3-year time slices: 1999-2001 (2000) for the present-day climate and 2049-2051 (2050) for the future climate.

\subsection{Surface Ozone Observations and Gridded Daily Maximum Temperatures}

Hourly ozone concentrations data from non urban stations in Europe for the years 1999-2001 are retrieved from the EMEP program database (http:// www.nilu.no/projects/ccc/emepdata.html). In addition, stations are selected to be located at an elevation lower than $1000 \mathrm{~m}$ (due to poor representation of mountainous areas in the model; Vautard et al. 2009) and provide data for at least $18 \mathrm{~h}(75 \%)$ within a day. Based on the aforementioned criteria 65 stations are analyzed. The locations of the stations are shown in Fig. 1 with the majority of the stations having available data for the aforementioned years located in Central and Northern Europe. For the purposes of this

Table 1 Anthropogenic and natural emissions of ozone precursors for the 2000 and the 2050 period under the A1B future emissions scenario

\begin{tabular}{|c|c|c|c|c|c|c|}
\hline \multirow[t]{2}{*}{ Species } & \multicolumn{3}{|c|}{ Europe } & \multicolumn{3}{|c|}{ World } \\
\hline & 2000 & 2050 & Relative change (\%) & 2000 & 2050 & Relative change (\%) \\
\hline \multicolumn{7}{|l|}{$\mathrm{NO}_{x}(\mathrm{Tg} \mathrm{N})$} \\
\hline Fossil fuel combustion $^{\mathrm{a}}$ & 4.7 & 5.4 & 13 & 23 & 46 & 97 \\
\hline Biomass burning $^{\mathrm{a}}$ & 0.06 & 0.04 & -26 & 6.5 & 8.1 & 25 \\
\hline Biofuel $^{\mathrm{a}}$ & 0.2 & 0.1 & -51 & 2.2 & 2.1 & -4.8 \\
\hline Lightning $^{\mathrm{b}}$ & 0.05 & 0.05 & 0 & 3.5 & 4.1 & 17 \\
\hline Soil $^{\mathrm{b}}$ & 0.36 & 0.40 & 11 & 6.2 & 6.6 & 6 \\
\hline \multicolumn{7}{|l|}{$\mathrm{CO}(\mathrm{Tg} \mathrm{CO})$} \\
\hline Fossil fuel combustion $^{\mathrm{a}}$ & 51 & 34 & -33 & 359 & 438 & 22 \\
\hline Biomass burning $^{\mathrm{a}}$ & 6 & 5 & -15 & 460 & 749 & 62 \\
\hline Biofuel $^{\mathrm{a}}$ & 14 & 7 & -50 & 173 & 166 & -4 \\
\hline \multicolumn{7}{|l|}{ NMVOCs (Tg C) } \\
\hline Anthropogenic ${ }^{\mathrm{a}, \mathrm{b}}$ & 1.4 & 1.2 & -14 & 26 & 61 & 134 \\
\hline Biomass burning ${ }^{\mathrm{a}, \mathrm{b}}$ & 0.7 & 0.3 & -57 & 7.2 & 6.9 & -4 \\
\hline Isoprene $^{c}$ & 9 & 12 & 33 & 443 & 575 & 30 \\
\hline Other Biogenic ${ }^{\mathrm{c}, \mathrm{d}}$ & 5.9 & 7.2 & 22 & 158 & 189 & 20 \\
\hline
\end{tabular}

\footnotetext{
${ }^{a}$ Results are based on the base year anthropogenic emissions inventory (2000)

${ }^{\mathrm{b}}$ NMVOCs include acetone, alkenes and alkanes

${ }^{\mathrm{c}}$ Results are based on the 3-year averages for the present (1999-2001) and the future climate (2049-2051)

${ }^{\mathrm{d}}$ NMVOCs include acetone, alkenes and monoterpenes
} 


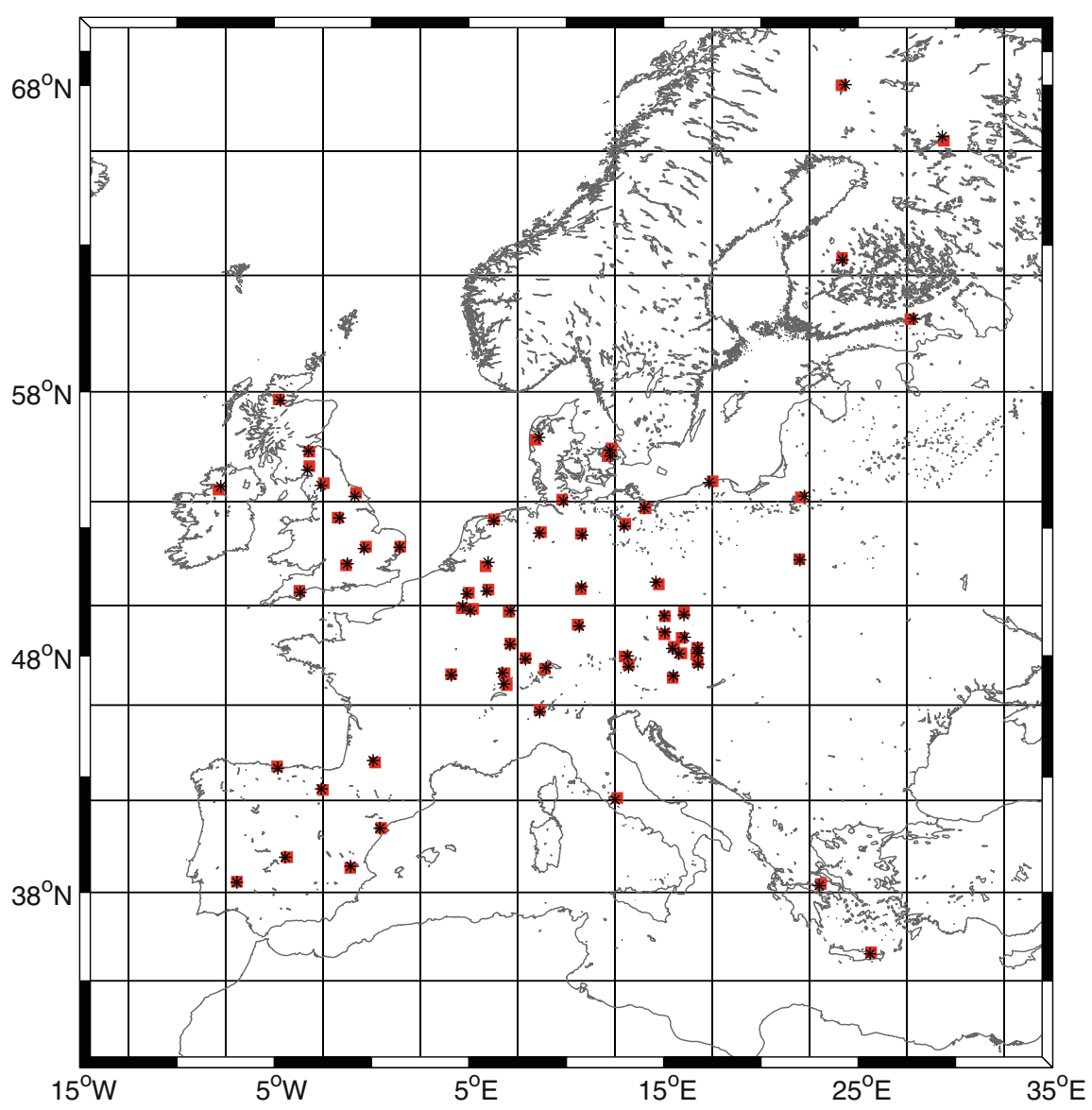

Fig. 1 Locations of the ozone stations (red squares) as well as the centers of the closest grid points (black asterisks) to each ozone station. The overplotted grid lines indicate the GISS/GEOS-CHEM grid squares

study the daily maximum 8 -h averages are used (EU Directive 2008/50/EC, 2008).

For temperature, daily maximum surface temperatures are gathered from the E-OBS daily gridded dataset (Haylock et al. 2008) developed under the framework of the ENSEMBLES project (www.ensembles-eu.org). E-OBS is a high-resolution dataset derived from statistically interpolated ground based station data over Europe. In the current study, daily maximum temperatures for the grid point closest (horizontal resolution $0.22^{\circ} \times 0.22^{\circ}$ ) to the ozone stations are used. As shown in Fig. 1, the grid points chosen for our analysis are, in most of the cases, located very close to the ozone stations, whereas in some cases the center of the grid point coincides with the location of the ozone stations. It should be noted here that previous studies that have examined the behavior of the E-OBS daily maximum temperatures against other gridded interpolation products or observations in different
European areas have yielded different results. In particular, Kyselý and Plavcová (2010) found that the E-OBS upper tail of summer daily maximum temperature is too cold when compared to a gridded dataset from a high density network of stations over two regions in the Czech Republic, whereas Hofstra et al. (2009) and Kostopoulou et al. (2012) found that the E-OBS satisfactory reproduces trends in extreme temperatures when compared against to a gridded dataset in the UK and station observations across the NE Mediterranean subregion, respectively. Nevertheless, caution is needed in areas of high elevation since interpolation degrades with increasing altitude (Hofstra et al. 2009; Kostopoulou et al. 2012). All results presented in this study are 3year averages and are calculated over the warm period of the year (April 1-September 30, hereafter AMJJAS) where daily maximum ozone peaks and exceedances (Andersson and Engardt 2010; Varotsos et al. 2013) usually occur. 


\subsection{Methods of Analysis}

Evaluation of the GISS/GEOS-CHEM modeling system has been presented in two studies covering the U.S. (Wu et al. 2007, 2008) where the model's performance was compared against climatological ozonesonde data and GEOS-driven simulations (Wu et al. 2007) as well as observed ozone pollution episodes ( $\mathrm{Wu}$ et al. 2008). In this study, we follow the methodology introduced by Rasmussen et al. (2012) where a mechanistic approach to evaluate GCMs based on the ozone-temperature relationship was presented. This approach was based on the assumption that the strong correlation of ozone with temperature is associated with the intensity of surface air ventilation, since high temperatures occur under the presence of light winds, high levels of insolation and stagnant circulation conditions (Jacob et al. 1993). The variations of temperature (which are associated with ozone variations) encompass effects such as the thermal decomposition of PAN, temperature dependent biogenic emissions such as isoprene as well as the load of anthropogenic emissions ( $\mathrm{NO}_{x}$ and VOC) (Sillman and Samson 1995) that enhance local ozone production. To this aim, we compare the bivariate relationship within the model against the observed using two approaches. First, by utilizing the Pearson correlation coefficients $(r)$ between the daily maximum 8 -h average ozone concentrations and the daily maximum temperatures. Second, by taking the slope of the best fit line between the two variables (hereafter $\mathrm{mO} 3-\mathrm{T}$ ) as defined from the reduced major axis (RMA) method. According to Rasmussen et al. (2012), a fair representation between a modeling system and observations may be considered as a positive first step upon building confidence for the future models results. In particular, this method assumes that variables represented in both axes are subject to errors (Smith 2009; Rasmussen et al. 2012) in contrast to the ordinary least square method which assumes that the variable in the $x$ axis is measured without error. The mO3-T slope as derived from RMA is the ratio of the standard deviations of ozone and temperature, whereas the sign of the slope is obtained from the correlation coefficient. A positive slope indicates an ozone increase with an increase in temperature, whereas a negative slope indicates an ozone decrease with an increase in temperature.

\section{Model Evaluation}

In Fig. 2, the correlation coefficients between the daily maximum 8 -h average ozone concentrations and the daily maximum temperatures are presented for both the observations and the GISS/GEOSCHEM modeling system. It is evident that higher correlation coefficients between the two variables are calculated in the modeling system when compared to the observed indicating the driving role of temperature in the ozone formation within the GISS/GEOS-CHEM modeling system. In particular, in Fig. 2a it is shown that the highest observed correlation coefficients $(0.4-0.6)$ are evident for the majority of the grid squares covering central and south west Europe whereas anti-correlation between the two variables? $(<0)$ is evident in the south easterly and north easterly grid boxes of the domain. The results in each of these particular grid squares are obtained from only one ozone measuring station, therefore are subject to the quality of its data. In contrast, a more homogeneous spatial behavior of the correlation coefficients between the two variables is apparent for the modeling system. In Fig. 2b, it is clear that higher correlation coefficients $(>0.5)$ are calculated for most of the regions of Europe with the highest $(\sim 0.9)$ evident in central, south east and south west Europe whereas even negative correlation coefficients are found in the northern areas of Europe.

Regarding the slope of the two variables, the GISS/GEOS-CHEM reproduces quite well the positive mO3-T values in central and south west Europe indicating, however, lower values than the observed but with the deviations not exceeding $0.6 \mathrm{ppb}{ }^{\circ} \mathrm{C}^{-1}$ (Fig. 3a and b). In the northern areas, both the east and the west, negative $\mathrm{mO} 3$ $\mathrm{T}$ values are evident for both the observations and the modeling system indicating that the increase in maximum temperature has no effect on the daily maximum 8-h average ozone concentrations and hence ozone levels are controlled by other factors such as snow cover. Furthermore, there are two grid squares covering the south east areas of the United Kingdom and the Benelux region where the GISS/GEOS-CHEM clearly overestimates the observed mO3-T values (in the range of $4 \mathrm{ppb}{ }^{\circ} \mathrm{C}^{-1}$ ) indicating a poor representation of the observed ozone-temperature relationship. 


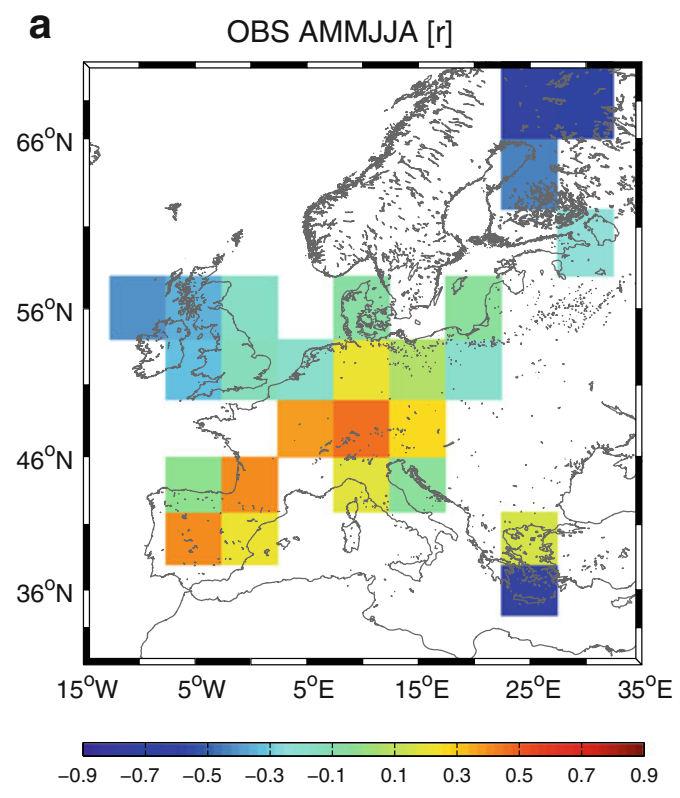

Fig. 2 Pearson correlation coefficients between daily maximum 8-h average ozone concentrations and daily maximum temperature for the April-September period for the a observations,

\section{Climate Change and Meteorological Variables Affecting Ozone Levels}

Previous modeling studies that have examined the sensitivity of ozone to meteorology (Jacob and Winner

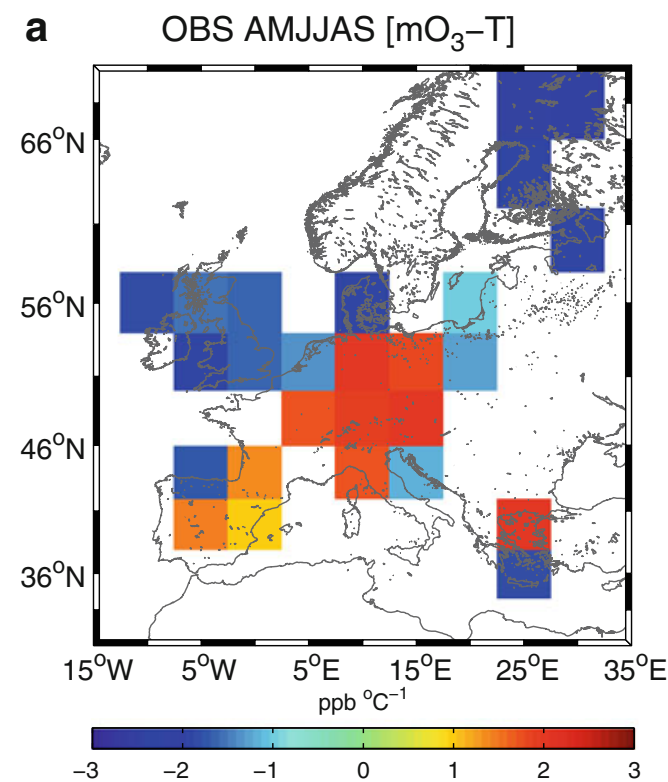

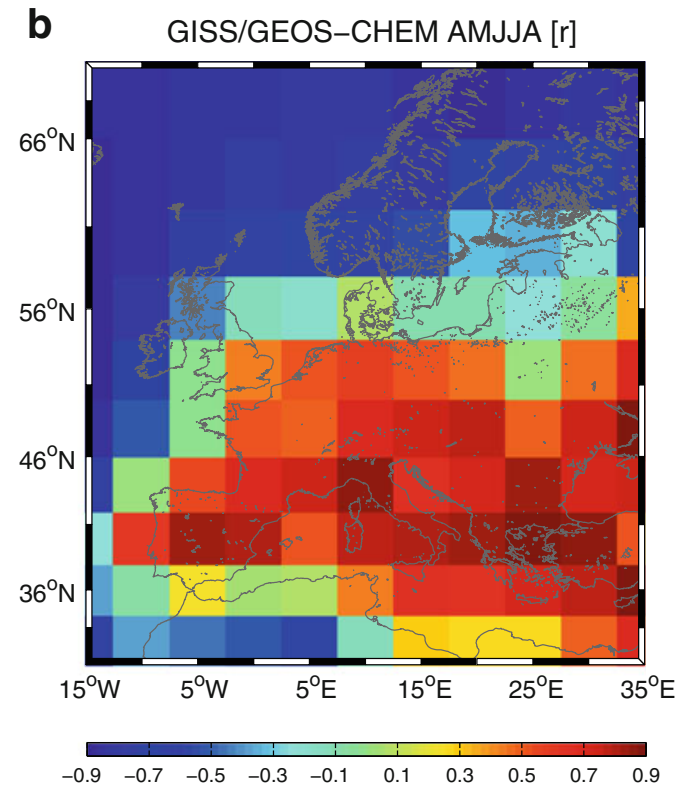

after averaging over the stations located to a GISS (Goddard Institute for Space Studies)/GEOS-CHEM grid square and $\mathbf{b}$ GISS/GEOS-CHEM

2009 and references therein) as well as studies that have examined climate change impacts on ozone levels have associated changes in ozone with changes in various meteorological variables (Katragkou et al. 2011 and references therein). Among these variables temperature

\section{b GISS/GEOS-CHEM AMJJAS $\left[\mathrm{mO}_{3}-\mathrm{T}\right]$}

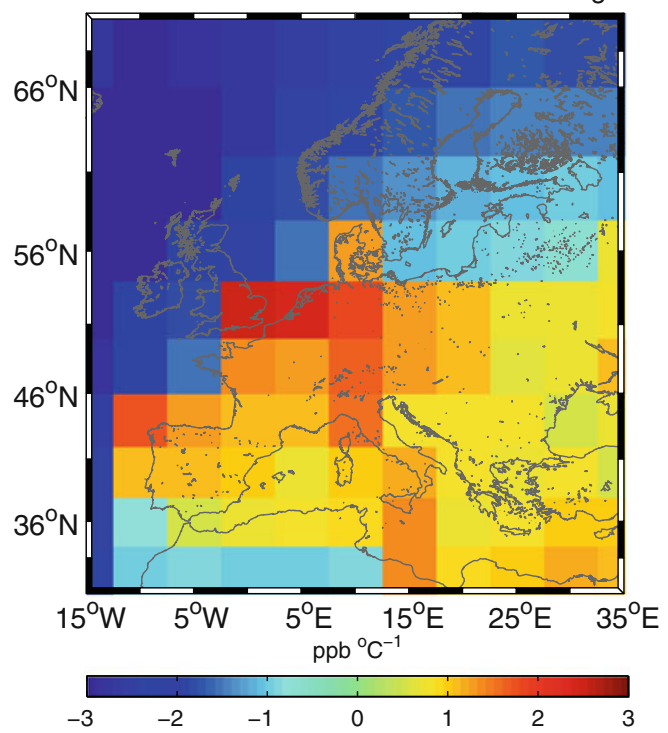

Fig. 3 The best-fit line slopes as derived from RMA for the April-September period for the a observations, after averaging over the stations located to a GISS/GEOS-CHEM grid square and b GISS/GEOS-CHEM 
has been found to have the strongest effect on ozone levels in all studies with the two variables exhibiting a high correlation coefficient due to the reasons mentioned in the previous section. In addition, other variables such as solar radiation, water vapor, mixing height, wind speed and direction and snow cover also play a role in ozone changes. However, their impact on ozone concentrations is not as straightforward as the impact of temperature (Jacob and Winner 2009). Figure 4 shows the mean AMJJAS simulated changes between future and present-day climate for temperature, solar radiation, mixing height, relative humidity and wind speed. It should be noted here that only statistical significant changes at the $95 \%$ level as derived by the bootstrap confidence intervals (Efron 1987; DiCiccio and Efron 1996) are plotted. Highest temperature changes are seen in the western areas of the European domain whereas smaller changes are shown for the eastern ones (Fig. 4a). More specifically, temperatures increase by $2-2.5^{\circ}$ in the west and southwest and by $1^{\circ}$ in the east. Moderate increases of about $1-1.5^{\circ}$ are shown over Scandinavia, parts of central Europe as well as over southeastern Europe (Italy and Greece). Increases of solar radiation (Fig. 4b) in the northwest are accompanied by increases in regional mixing height (Fig. 4c) whereas decreases are shown for both variables in eastern, northern and southern Europe. In addition changes in mixing height and relative humidity are spatially anti-correlated. Mixing height increases are apparent for the northwest (Great Britain) and northern Europe (Scandinavian region) (Fig. 4c), whereas increases in relative humidity are shown for the central, southern and eastern Europe (Fig. 4d). Regarding winds, the highest increases are shown for the central and south-east Europe (Fig. 4e).

\section{Changes in Ozone Concentrations}

\subsection{Changes due to Climate Change}

In Fig. 5, results for the average daily maximum 8-hr average ozone concentrations over the period of April-September under the present climate and present emissions (SCEN_1) as well as the changes between SCEN_2 and SCEN_1 are shown. It is evident that the impact of climate change on its own leads to an increase of less than $3 \mathrm{ppb}$ in western and central Europe whereas decreases are also evident for most of the remaining areas with the highest (about $2.5 \mathrm{ppb}$ ) in southeastern Europe (Italy, Greece). The aforementioned increases are a combination of higher temperatures, solar radiation and mixing depths. In addition, ozone increases due to increases of isoprene biogenic emissions (Fig. 6) associated with the temperature increases as well as lower PAN stability (Jacob et al. 1993; Sillman and Samson 1995; Wu et al. 2008). In contrast to the northwest, small decreases of ozone are apparent in the south west (Iberian Peninsula). These decreases are partly associated with the increases of isoprene emissions in the model under low $\mathrm{NO}_{x}$ levels leading to sequestration of $\mathrm{NO}_{x}$ as isoprene nitrates (Wu et al. 2007, 2008), direct ozonolysis of isoprene (Fiore et al. 2005; Wu et al. 2008), the increased winds projected for the 2050 climate (Fig. 4e) as well as with a small decrease in mixing height in the specific region (Fig. 4c). Decreases of the same magnitude or slightly higher are evident for the northern parts of the study domain which may be attributed to decreases in snow cover leading to increases in the dry deposition of ozone (Andersson and Engardt 2010) as well as the decrease in solar radiation leading to weaker photochemical ozone production. Finally, the greatest decreases are shown in South east Europe associated with the increase of water vapor overseas which tend to decrease the lifetime of ozone (Johnson et al. 1999; Langner et al. 2012) as well as the increased wind speeds in the 2050 climate. Our results regarding northwest, central continental as well as northern Europe are comparable to those presented by Anderson and Endgart (2010) while results of the opposite sign are shown for southern Europe. In their study, they examined the changes for the period AprilSeptember (2021-2050 versus 1961-1990) using the MATCH chemical transport model driven by the RCA3 regional climate model with the future simulation conducted under the A2 future emissions scenario. More specifically, they have shown an increase of about 2-4 ppb in the daily ozone maximum extending from north west and south west Europe to central and Southeast Europe (Italy, Greece), attributed to the enhanced isoprene biogenic emissions as well as to the decrease of ozone dry deposition. Note that the increase found in southern Europe is in contrast to our results and can be attributed to the different time slice examined (2071-2100) and the different future emissions scenario used in their simulations - A2 as opposed to the milder A1B emissions scenario used 

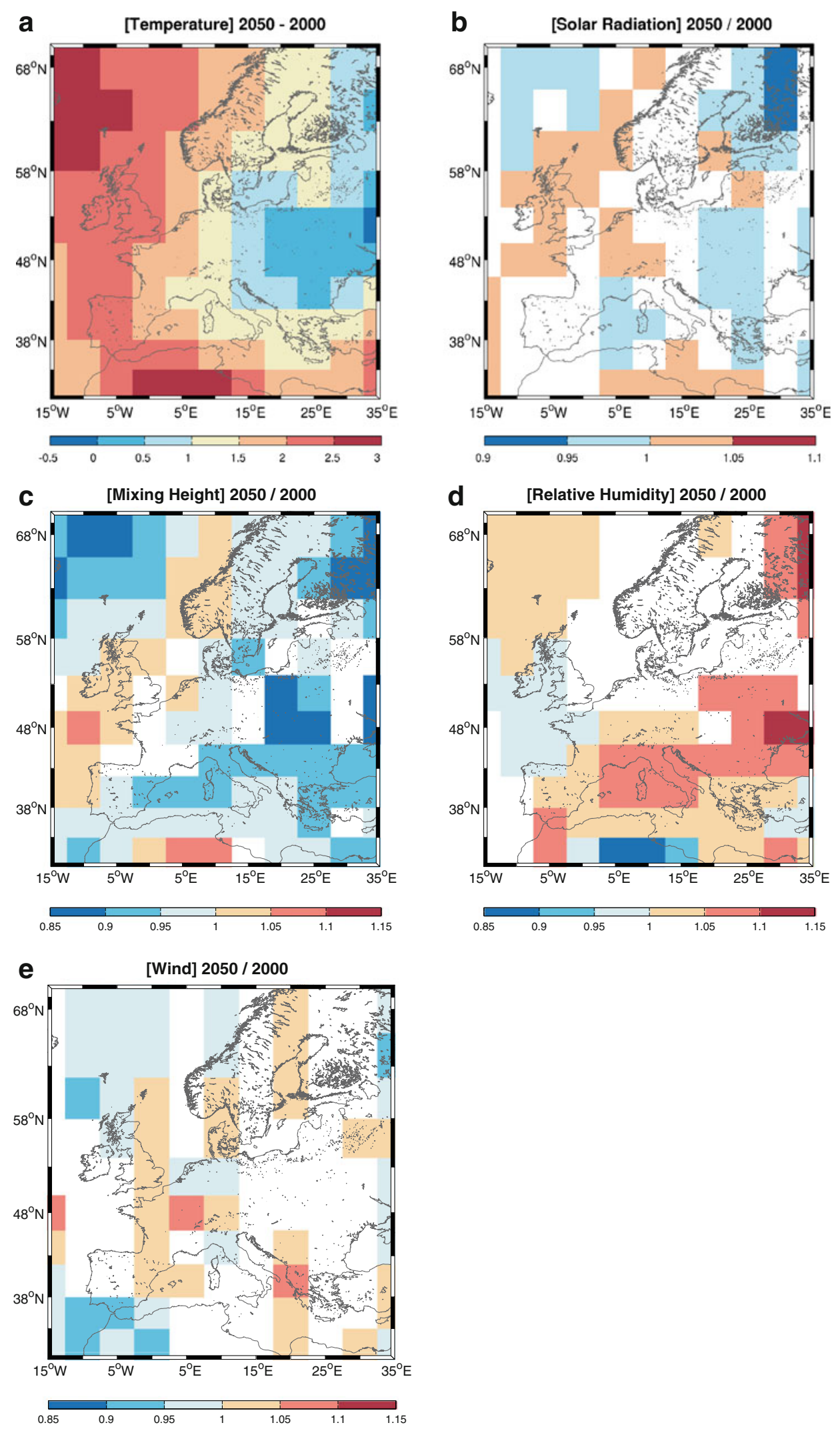
Fig. 4 Mean April-September simulated changes between future (2050) and present-day (2000) climate for a temperature and ratios for $\mathbf{b}$ solar radiation, $\mathbf{c}$ mixing height, $\mathbf{d}$ relative humidity and $\mathbf{e}$ wind speed. Only statistically significant changes for the $95 \%$ level of significance are plotted

here. However, it should be noted here that Langner et al. (2012) examining ozone changes between the 2050 and present-day climate using the MATCH-RCA3 modeling system under the A1B future emissions scenario, as a member of a multi chemical transport model ensemble study, found that decreases over the Mediterranean Sea were collocated with increases of relative humidity. In accordance to our results, in both studies simulated decreases of about 1-2 ppb were found in the northern areas of Europe (Scandinavia).

\subsection{Changes due to Climate Change and Future Emissions}

When future emissions are implemented in the simulations, a different pattern in the changes of ozone concentrations is evident (Fig. 7b) mainly due to the changes in the ozone precursor emissions $\left(\mathrm{NO}_{x}, \mathrm{CO}\right.$ and NMVOCs, Jonson et al. 2006). For instance, European anthropogenic $\mathrm{NO}_{x}$ is estimated to increase under the A1B future emission scenario by $13 \%$
(Table 1), whereas $\mathrm{CO}$ and NMVOCs are expected to decrease by $33 \%$ and $14 \%$, respectively (Table 1 ). However, these changes are not uniformly distributed in the European domain. For instance, for $\mathrm{NO}_{x}$, which is important for ozone formation, increases are projected in Southern Europe as well as in north east Europe (Poland) whereas decreases are found in the north west (British Isles, Netherlands, Belgium), west (France) and central Europe (Switzerland, Germany) (not shown). Insignificant changes or slight reductions are expected for the rest of Europe (not shown). Consequently, the high increases in the continental Europe and in the Mediterranean (about $16 \mathrm{ppb}$ ) are due to the higher levels of $\mathrm{NO}_{x}$ within a rich biogenic isoprene environment. Lower increases (up to $8 \mathrm{ppb}$ ) are projected in Eastern Europe due to the $\mathrm{NO}_{x}$ increases. Similar increases are shown in the region between Great Britain and the Netherlands where the highest decreases in $\mathrm{NO}_{x}$ are projected for the future. This behavior (ozone increases under decreasing $\mathrm{NO}_{x}$ ) in the aforementioned area has also been documented in a recent study (Beekmann and Vautard 2010) and is attributed to the ozone formation chemical regime. According to this study, a uniform reduction of $30 \%$ in $\mathrm{NO}_{x}$ emissions causes increases in the daily ozone maximum concentrations (higher than $3 \mathrm{ppb}$ ) with the most pronounced changes being evident in the channel
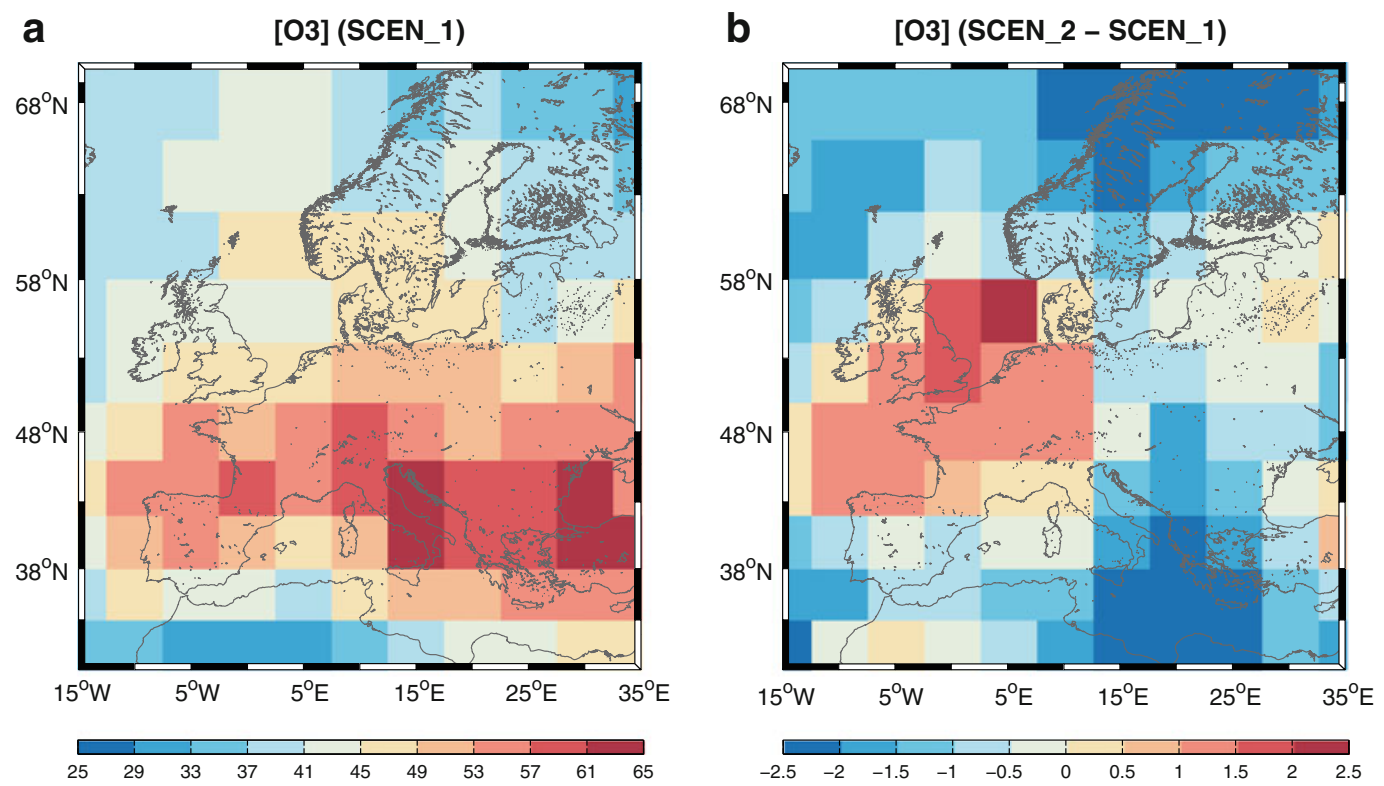

Fig. 5 Simulated daily maximum 8-h average $\mathrm{O}_{3}$ for the warm period a averaged under present-day conditions (SCEN_1) and b changes between 2050 climate change and present day (SCEN_2-SCEN_1). All units are in ppb 

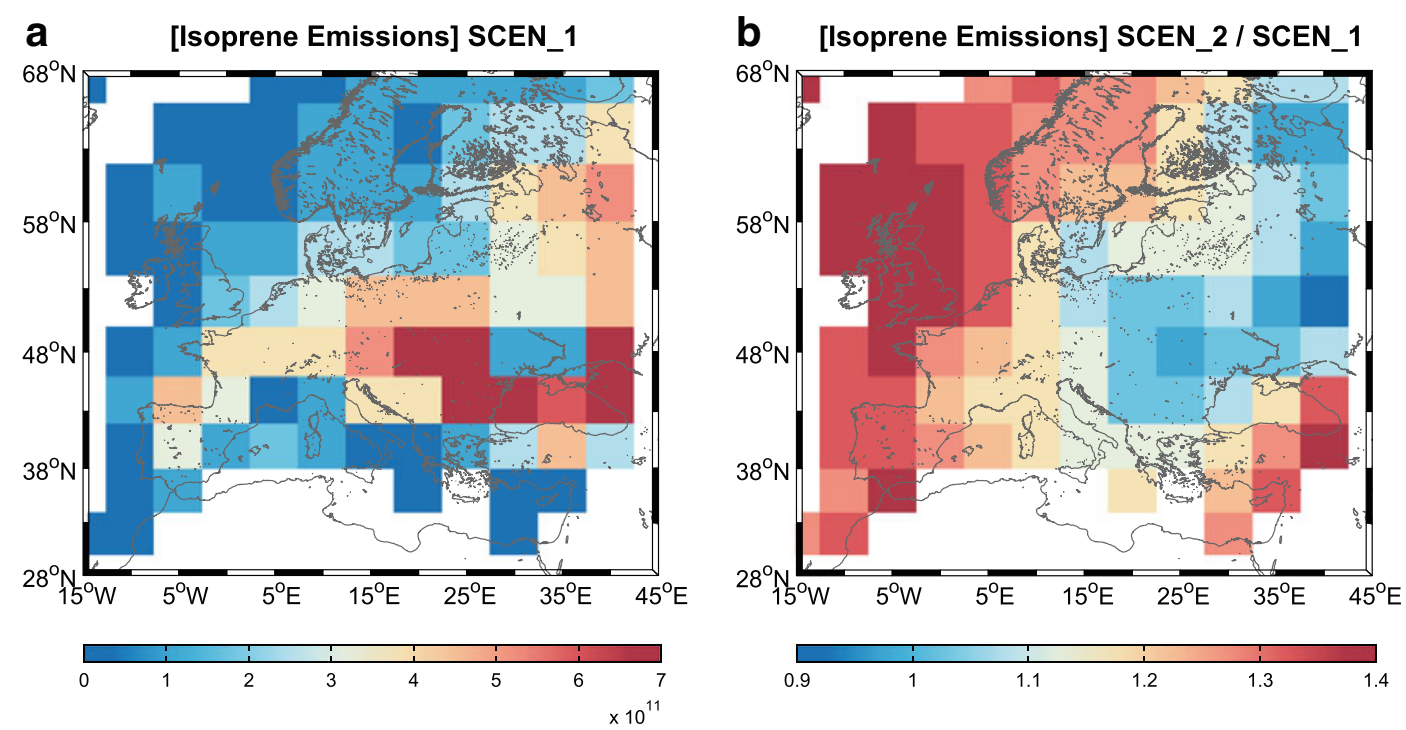

Fig. 6 Mean Isoprene emissions for the warm period for a present climate (in atoms $\mathrm{C} / \mathrm{cm}^{2} / \mathrm{s}$ ) and $\mathbf{b}$ the ratios between $2050 \mathrm{climate}$ and 2000

region and the greater Paris area. However, in this study the phenomenon is obvious only in the area between Great Britain and the Netherlands and does not extend further south. Decreases up to $2 \mathrm{ppb}$ of ozone are shown for France, Switzerland and Northern Italy attributed to the low levels of $\mathrm{NO}_{x}$ and the increase in isoprene emissions as described in the previous section. Two other features arise from Fig. $7 \mathrm{a}$ and $\mathrm{b}$ that associate the changes in the meteorological variables due to climate change with the changes in the anthropogenic emissions and especially $\mathrm{NO}_{x}$ anthropogenic emissions. Primarily, it is evident that the increase in water vapor and wind speed over the South East Europe limits the increase in ozone (by about $2 \mathrm{ppb}$ ) due to the increased projected $\mathrm{NO}_{x}$ emissions. Secondly, in northern Europe the reductions in snow cover and solar radiation might
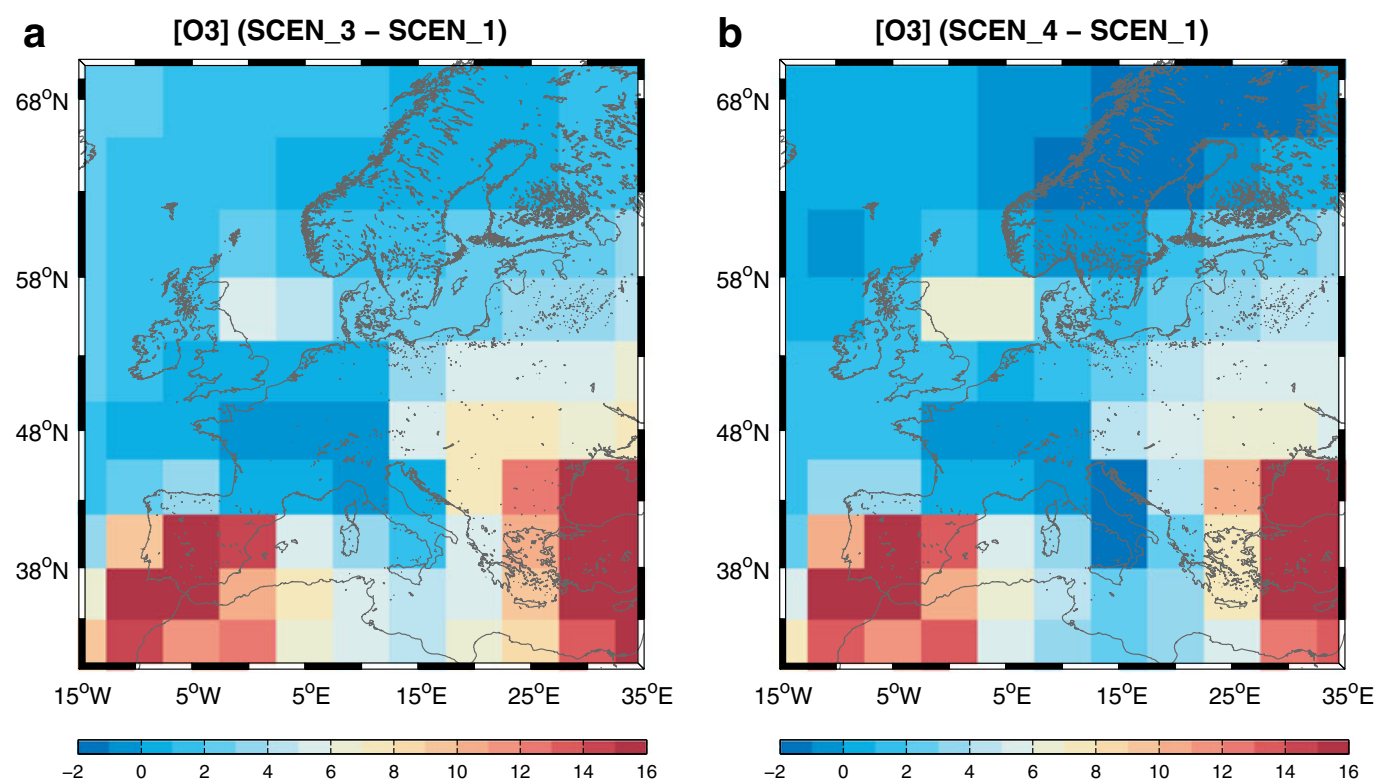

Fig. 7 Simulated changes of the daily maximum 8-h average $\mathrm{O}_{3}$ for the warm period a between 2000 climate with 2050 emissions and present day (SCEN_3-SCEN_1) and $\mathbf{b}$ between 2050 climate and emissions and present day (SCEN_4-SCEN_1). All units are in ppb 
have a positive effect leading to ozone decreases of about 2 ppb.

\section{Conclusions}

We performed a full assessment of the impacts of climate change on European ozone levels using simulations from the global chemical transport model GEOSCHEM driven by meteorological variables from the GISS-GCM. To isolate the effects from changes in climate and anthropogenic emissions four types of simulations were performed: (1) present-day climate and emissions, (2) future climate following the IPCC SRES A1B scenario and present day anthropogenic emissions of ozone precursors, (3) present-day climate and future emissions and (4) future climate and emissions. We focused over the period 1 April-30 September where ozone production is at its peak and all results presented here are 3-year averages.

We evaluated the GISS/GEOS-CHEM modeling system following the methodology introduced by Rasmussen et al. (2012) where a mechanistic approach to evaluate GCMs based on the ozone-temperature relationship was presented. To this aim, the bivariate relationship within the model against the observed was used utilizing: (a) the Pearson correlation coefficients $(r)$ between the daily maximum 8-h average ozone concentrations and the daily maximum temperature and (b) the slope of the best fit line between the two variables (mO3T) as defined from the RMA method. The comparison indicated a more homogeneous spatial behavior of the correlation coefficients between the two variables within the modeling system with higher correlation coefficients $(>0.5)$ calculated for most of the regions in Europe. The highest correlation coefficients $(\sim 0.9)$ were evident in central, south east and south west Europe whereas negative ones were evident in the northern areas of Europe. Regarding the ozone-temperature relationship, the GISS/GEOS-CHEM reproduced quite well the positive mO3-T values in central and south west Europe indicating, however, lower values than those observed but with the deviations not exceeding $0.6 \mathrm{ppb}^{\circ} \mathrm{C}^{-1}$.

Regarding climate change impacts, our results indicated that climate change impact on its own caused an increase of less than $3 \mathrm{ppb}$ in western and central Europe whereas decreases were evident for the rest of the areas with the highest (about $2.5 \mathrm{ppb}$ ) in southeastern Europe (Italy, Greece). Increases were associated with increased isoprene biogenic emissions due to increased temperatures whereas the decreases were associated with the increase of water vapor over sea as well as increased wind speeds in the 2050 climate. Lower decreases in daily maximum ozone concentrations were also simulated in northern Europe attributed to increased dry deposition due to decreases in snow cover and reduced solar radiation in future climate. When future emissions were implemented in the simulations the greatest increases were simulated in continental Europe and in the south west and south east Mediterranean (easterly of Greece, about $16 \mathrm{ppb}$ ) due to the increased isoprene biogenic under higher levels of $\mathrm{NO}_{x}$ in the model. Decreases up to $2 \mathrm{ppb}$ of ozone were shown for France, Switzerland and Northern Italy attributed to the low levels of $\mathrm{NO}_{x}$ and the increase in isoprene emissions. In addition, our simulation revealed that the increase in water vapor and wind speed over the South East Europe (area between Italy and Greece) limits the increase in ozone (by about $2 \mathrm{ppb}$ ) due to the increased projected $\mathrm{NO}_{x}$ emissions. Finally, in northern Europe the reductions in snow cover and solar radiation were found to have a positive effect leading to ozone decreases of about $2 \mathrm{ppb}$.

Acknowledgments This research has been co-financed by the European Union (European Social Fund [ESF]) and Greek national funds through the Operational Program "Education and Lifelong Learning" of the National Strategic Reference Framework (NSRF) - Research Funding Program: Heracleitus II. Investing in knowledge society through the European Social Fund.

\section{References}

Andersson, C., \& Engardt, M. (2010). European ozone in a future climate: importance of changes in dry deposition and isoprene emissions. Journal of Geophysical Research, 115, D02303. doi:10.1029/2008JD011690.

Auvray, M., Bey, I. (2005). Long-range transport to Europe: seasonal variations and implications for the European ozone budget. Journal of Geophysical Research: Atmospheres 110:n/a-n/a. doi: 10.1029/2004JD005503

Beekmann, M., \& Vautard, R. (2010). A modelling study of photochemical regimes over Europe: robustness and variability. Atmospheric Chemistry and Physics, 10, 1006710084. doi:10.5194/acp-10-10067-2010.

Bell, M. L., Goldberg, R., Hogrefe, C., Kinney, P. L., Knowlton, K., Lynn, B., Rosenthal, J., Rosenzweig, C., \& Patz, J. A. (2007). Climate change, ambient ozone, and health in 50 US cities. Climatic Change, 82(61-76), 2007.

DiCiccio, T. J., \& Efron, B. (1996). Bootstrap confidence intervals. Statistical Science, 11, 189-228. doi:10.1214/ss/1032280214.

Directive 2008/50/EC of the European Parliament and of the Council of 21 May 2008 on ambient air quality and cleaner 
air for Europe (http://www.eea.europa.eu/policy-documents/ directive-2008-50-ec-o).

Duncan, B.N., Bey, I., (2004). A modeling study of the export pathways of pollution from Europe: seasonal and interannual variations (1987-1997). Journal of Geophysical Research: Atmospheres 109:n/a-n/a. doi:10.1029/2003JD004079

Efron, B. (1987). Better bootstrap confidence intervals. Journal of the American Statistical Association, 82, 171. doi:10.2307/ 2289144.

Fiore, A. M., Horowitz, L. W., Purves, D. W., et al. (2005). Evaluating the contribution of changes in isoprene emissions to surface ozone trends over the eastern United States. Journal of Geophysical Research, 110, D12303. doi:10.1029/2004JD005485.

Forkel, R., \& Knoche, R. (2006). Regional climate change and its impact on photooxidant concentrations in southern Germany: simulations with a coupled regional climatechemistry model. Journal of Geophysical Research, 111(D12), D12302. doi:10.1029/2005JD006748.

Forkel, R., \& Knoche, R. (2007). Nested regional climate-chemistry simulations for central Europe. Comptes Rendus Geoscience, 339(11-12), 734-746. doi:10.1016/j.crte.2007.09.018.

Giorgi, F., \& Meleux, F. (2007). Modelling the regional effects of climate change on air quality. Comptes Rendus Geoscience, 339(11-12), 721-733. doi:10.1016/j.crte.2007.08.006.

Guerova, G., \& Jones, N. (2007). A global model study of ozone enhancement during the August 2003 heat wave in Europe. Environmental Chemistry, 4, 285-292.

Haylock, M.R., Hofstra, N., Klein Tank, A.M.G., et al. (2008). A European daily high-resolution gridded data set of surface temperature and precipitation for 1950-2006. Journal of Geophysical Research: Atmospheres 113:(D20), D20119 doi:10.1029/2008JD010201

Hedegaard, G. B., Brandt, J., Christensen, J. H., et al. (2008). Impacts of climate change on air pollution levels in the Northern Hemisphere with special focus on Europe and the Arctic. Atmospheric Chemistry and Physics, 8, 3337-3367. doi:10.5194/acp-8-3337-2008.

Hofstra N., Haylock, M., New, M., Jones, P.D., (2009). Testing EOBS European high-resolution gridded data set of daily precipitation and surface temperature. Journal of Geophysical Research: Atmospheres 114:(D21), D21101 doi:10.1029/ 2009JD011799

Jacob, D. J., \& Winner, D. A. (2009). Effect of climate change on air quality. Atmospheric Environment, 43, 51-63. doi:10.1016/ j.atmosenv.2008.09.051.

Jacob, D. J., Logan, J. A., Gardner, G. M., et al. (1993). Factors regulating ozone over the United States and its export to the global atmosphere. Journal of Geophysical ResearchAtmospheres, 98, 14817-14826. doi:10.1029/98JD01224.

Johnson, C. E., Collins, W. J., Stevenson, D. S., \& Derwent, R. G. (1999). Relative roles of climate and emissions changes on future tropospheric oxidant concentrations. Journal of Geophysical Research, 104, 18631-18,645. doi:10.1029/ 1999JD900204.

Jonson, J. E., Simpson, D., Fagerli, H., \& Solberg, S. (2006). Can we explain the trends in European ozone levels? Atmospheric Chemistry and Physics, 6, 51-66. doi:10.5194/acp-6-51-2006.

Katragkou, E., Zanis, P., Kioutsioukis, I., et al. (2011). Future climate change impacts on summer surface ozone from regional climate- air quality simulations over Europe. Journal of Geophysical Research, 116, D22307. doi:10.1029/2011JD015899.

Kostopoulou, E., Giannakopoulos, C., Hatzaki, M., \& Tziotziou, K. (2012). Climate extremes in the NE Mediterranean: assessing the E-OBS dataset and regional climate simulations. Climate Research, 54, 249-270. doi:10.3354/cr01110.

Kyselý, J., \& Plavcová, E. (2010). A critical remark on the applicability of E-OBS European gridded temperature data set for validating control climate simulations. Journal of Geophysical Research. doi:10.1029/2010JD014123.

Langner, J., Bergström, R., \& Foltescu, V. (2005). Impact of climate change on surface ozone and deposition of sulphur and nitrogen in Europe. Atmospheric Environment, 39, 1129-1141. doi:10.1016/j.atmosenv.2004.09.082.

Langner, J., Engardt, M., Baklanov, A., et al. (2012). A multimodel study of impacts of climate change on surface ozone in Europe. Atmospheric Chemistry and Physics Discussions, 12, 4901-4939. doi:10.5194/acpd-12-4901-2012.

Leung, L.R., Gustafson, W.I., (2005). Potential regional climate change and implications to U.S. air quality. Geophysical Research Letters 32:n/a-n/a. doi:10.1029/2005GL022911

Meleux, F., Solmon, F., \& Giorgi, F. (2007). Increase in summer European ozone amounts due to climate change. Atmospheric Environment, 41, 7577-7587. doi:10.1016/j.atmosenv.2007.05.048.

Mickley, L.J., Jacob, D.J., Field, B.D., Rind, D., (2004). Effects of future climate change on regional air pollution episodes in the United States. Geophysical Research Letters 31:n/an/a. doi:10.1029/2004GL021216

Nakicenovic, N., and Swart, R., (2000). Special Report on Emissions Scenarios. A Special Report of Working Group III of the Intergovernmental Panel on Climate Change. Cambridge University Press, Cambridge, UK, $570 \mathrm{pp}$

Protonotariou, A. P., Tombrou, M., Giannakopoulos, C., et al. (2010). Study of CO surface pollution in Europe based on observations and nested-grid applications of GEOS-CHEM global chemical transport model. Tellus B, 62, 209-227. doi:10.1111/j.1600-0889.2010.00462.x.

Rasmussen, D. J., Fiore, A. M., Naik, V., et al. (2012). Surface ozone-temperature relationships in the eastern US: a monthly climatology for evaluating chemistry-climate models. Atmospheric Environment, 47, 142-153. doi:10.1016/j.atmosenv.2011.11.021.

Rind, D., Lerner, J., \& McLinden, C. (2001). Changes of tracer distributions in the doubled $\mathrm{CO}_{2}$ climate. Journal of Geophysical Research, 106, 28061. doi:10.1029/2001JD000439.

Selin, N. E., Wu, S., Nam, K. M., Reilly, J. M., Paltsev, S., Prinn, R. G., \& Webster, M. D. (2009). Global health and economic impacts of future ozone pollution. Environmental Research Letters, 4(4), 044014. doi:10.1088/1748-9326/4/4/044014

Sillman, S., \& Samson, P. J. (1995). Impact of temperature on oxidant photochemistry in urban, polluted rural and remote environments. Journal of Geophysical Research-Atmospheres, 100, 11497-11508. doi:10.1029/94JD02146.

Smith, R. J. (2009). Use and misuse of the reduced major axis for line-fitting. American Journal of Physical Anthropology, 140(3), 476-486. doi:10.1002/ajpa.21090.

Streets, D.G., Bond, T.C., Lee, T., Jang, C., (2004). On the future of carbonaceous aerosol emissions. Journal of 
Geophysical Research: Atmospheres 109:(D24), D24212 doi:10.1029/2004JD004902

Varotsos, K. V., Tombrou, M., \& Giannakopoulos, C., (2013). Statistical estimations of the number of future ozone exceedances due to climate change in Europe, J. Geophys. Res. Atmos., 118, doi:10.1002/jgrd.50451.

Vautard, R., Schaap, M., Bergström, R., et al. (2009). Skill and uncertainty of a regional air quality model ensemble. Atmospheric Environment, 43, 4822-4832. doi:10.1016/ j.atmosenv.2008.09.083.
Wu, S., Mickley, L. J., Jacob, D. J., Logan, J. A., Yantosca, R. M., \& Rind, D. (2007). Why are there large differences between models in global budgets of tropospheric ozone? Journal of Geophysical Research: Atmospheres, 112(D5), D05302. doi:10.1029/2006JD007801

Wu, S., Mickley, L. J., Leibensperger, E. M., Jacob, D. J., Rind, D., \& Streets, D. G. (2008). Effects of 2000-2050 global change on ozone air quality in the United States. Journal of Geophysical Research: Atmospheres, 113(D6), D06302. doi:10.1029/2007JD008917 